\section{Subirrigation to Root Stem cuttings: Comparison to Intermittent Mist and Influence of Fertilization}

\author{
Hongyi Zhang and \\ William R. Graves
}

\begin{abstract}
Additional index words. asexual propagation, chrysanthemum, Dendranthema $\times$ grandiflorum, Coleus $\times$ hybridus, red maple, Acer rubrum, Japanese tree lilac, Syringa reticulata
\end{abstract}

Summary. A subirrigation method for rooting stem cuttings was compared to intermittent mist. Both methods resulted in $100 \%$ rooting of 'Charm' chrysanthemum [Dendranthema $\times$ grandiflorum (Ramat.) Kitamura] and coleus (Coleus $\times$ hybridus Voss. ) after 2 weeks. Subirrigated cuttings of 'Charm' chrysanthemum had a lower mean root dry mass than misted cuttings, but root dry mass of coleus was not affected. Percentage rooting and mean root dry mass of subirrigated cuttings of 'Franksred' red maple (Acer rubrum L.) were $95 \%$ and $321 \mathrm{mg}$, whereas the mean root dry mass of the $33 \%$ of cuttings that rooted under mist was $38 \mathrm{mg}$. For Japanese tree lilac [Syringa reticulata (Blume) Hara], the percentage of cuttings with living callus, mean callus diameter, and percentage rooting were higher for subirrigated cuttings than for misted cuttings. In a second study, cuttings of 'Franksred' red maple were subirrigated with a solution containing 0 to $7.2 \mathrm{~mol} \mathrm{~N} / \mathrm{m}^{3}$ and not misted. Cuttings given 3.6 or $7.2 \mathrm{~mol}$ $\mathrm{N} / \mathrm{m}^{3}$ had $>90 \%$ rooting after 2

$\overline{\text { Department of Horticulture, Iowa State University, }}$ Ames, IA 50011-1100,

Journal paper no. J-15862 of the Iowa Agriculture and Home Economics Experiment Station, Ames, project no. 3229. We are grateful to Yoder Suppliers, Alva, Fla., and J. Frank Schmidt \& Son, Boring, Ore., for donating plant material. The cost of publishing this paper was defrayed in part by the payment of page charges, Under postal regulations, this paper therefore must be hereby marked advertisement solely to indicate this fact. weeks, whereas only $8 \%$ of unfertilized cuttings had rooted, and root mass and chlorophyll content were highest for cuttings given $7.2 \mathrm{~mol} \mathrm{~N} / \mathrm{m}^{3}$. Subirrigation can replace mist during propagation of some florist and nursery crops, and subirrigating with fertilizer solution improves rooting of 'Franksred' red maple.

S tern cuttings of broad-leaved plants commonly are held under mist or fog to prevent leaf desiccation before rooting (Dirr and Heuser, 1987; Hartmann et al., 1990). Leaf chlorosis and leaching of foliar nutrients can result from mist (Blazich, 1988; Good and Tukey, 1966; Morton and Boodley, 1969; Snyder, 1965). Nutrient-deficiency symptoms have been overcome by fertilizing misted cuttings (Feldman et al., 1987; Wott and Tukey, 1967), but fertilization is ineffective for some taxa (BoozeDaniels et al., 1984; Wott and Tukey, 1967). Other problems with mist include clogging of nozzles (James, 1980), sanitation (Hartmann et al., 1990; Wott and Tukey, 1967), and desiccation of leaves of newly rooted cuttings (Wilkins et al., 1995).

Zhang and Graves (1994) reported a method for rooting cuttings by using subirrigation instead of mist or fog in greenhouses with moderate relative humidity (MI). Greater than $90 \%$ rooting was achieved for several taxa by using subirrigation, and preliminary trials indicated that adding fertilizer to the subirrigation solution can increase rooting percentage and root mass of some taxa. Propagation of stem cuttings by using subirrigation may be a simple and economical alternative to mist or fog. This method keeps cuttings and benches free of water so that nutrient leaching and deterioration of greenhouse equipment can be avoided. Although results of initial trials were promising, subirrigation and mist have not been compared directly. An objective of this research was to compare these methods for rooting stem cuttings of 'Charm' chrysanthemum, coleus, 'Franksred' red maple, and Japanese tree lilac. A second objective was to determine how adding fertilizer to the subirrigation solution affects rooting.

\section{Materials and methods}

Comparison of subirrigation and mist. Two propagation treat- ments were imposed on cuttings of four taxa in a glasshouse. Treatments were replicated over time because of the impracticality of randomizing subirrigated and misted cuttings.

Terminal stem cuttings of 'Charm' chrysanthemum that were $9 \mathrm{~cm}$ long and had four or five leaves were obtained from Yoder Suppliers (Alva, Fla. ). Cut ends were dipped in tap er and then in Hormodin 1 (MSDAGVET, Rathway, N.J. ) powder containing $1 \mathrm{~g}$ IBA $/ \mathrm{kg}$. The four replications of treatments for this taxon began on 22 and 23 June and 13 and 16 July 1994. Terminal stem cuttings of coleus were taken from stock plants of one clone in a glasshouse. Cuttings of this taxon had four leaves, a length of $10 \mathrm{~cm}$, and were not treated with hormone. The four replications began on 22 and 29 June, 12 July, and 16 Aug. 1994. Treatments lasted 2 weeks for both herbaceous species. Cuttings of 'Franksred' red maple were taken from the fourth through eighth youngest nodes of stock plants propagated from stem cuttings and grown in a glasshouse. Cuttings of Japanese tree lilac were taken from the third through sixth nodes of wood formed in 1994 on one tree in the landscape. For both woody species, single-node cuttings with two leaves and 5-cm-long stems were used. Basipetal ends were dipped in tap water and then in Hormodin 3 (MSD-AGVET) powder containing 8 $\mathrm{g}$ IBA/kg before insertion in coarse perlite (Lite Weight Products, Kansas City, Kan. ). Two 2-cm-long epidermal wounds were made with a razor blade on opposite sides of the basipetal end of stems of Japanese tree lilac. Cuttings of 'Franksred' red maple were inserted 20 and 27 June, 30 July, and 2 Aug. 1994, and treatments lasted 4 weeks. The four replications for Japanese tree lilac began 23 and 30 June and 12 and 24 July 1994, and treatments lasted 10 weeks.

Cuttings were subirrigated in Jiffy trays (T.O. Plastics, Minneapolis) that were $51 \times 13 \times 6 \mathrm{~cm}$ and had bottom drainage holes. The trays were filled with coarse perlite. Ten cuttings of a taxon were inserted $3 \mathrm{~cm}$ (herbaceous species) or $4 \mathrm{~cm}$ (woody species) deep in each tray. Each tray was placed in a larger, unperforated flat (T.O. Plastics) that was $51 \times 40 \times 6 \mathrm{~cm}$. A solution of $7.2 \mathrm{~mol} \mathrm{~N} / \mathrm{m}^{3}$ from Peters Excel all-purpose $21 \mathrm{~N}-2.2 \mathrm{P}-16.6 \mathrm{~K}$ (Scotts, Marietta, Ga.) in tap water was 
used to irrigate the perlite from the top and create a 2-cm-deep layer of solution in the flats. This kept the solution level below the cut ends of the cuttings in the trays. Additional solution was added to trays twice a week to maintain the 2-cm depth. The electrical conductivity of the solution at the initiation of treatments was $1.1 \times 10-3$ $\mathrm{dS} \cdot \mathrm{m}^{-1}$, measured by using a conductivity meter (model 09-33 1-4; Hanna Instruments, Woonsocket, R.I.). Cuttings in the mist treatment were inserted in coarse perlite in Jiffy trays to the same depths used for subirrigated cuttings. The perlite was irrigated to container capacity with tap water immediately before cuttings were stuck. There were 10 cuttings of a taxon per tray. Trays were placed on a glasshouse bench where tap-water mist was provided for $15 \mathrm{sec}$ every $15 \mathrm{~min}$ from 0700 to $2000 \mathrm{HR}$.

Air temperature, $\mathrm{RH}$, and irradiance were similar for cuttings in the two treatments. All cuttings were exposed to natural irradiance through shadecloth that provided $40 \%$ exclusion placed $1.2 \mathrm{~m}$ above the bench. Mean \pm SD photosynthetic photon flux (PPF) at 1400 HR adjacent to the cuttings in June, July, and August was $180 \pm 30,197 \pm 5$, and $180 \pm 36$ $\mu \mathrm{mol} \cdot \mathrm{m}^{-2} \cdot \mathrm{s}^{-1}$, respectively. For subirrigated cuttings in June, July, and August, mean air temperature near subirrigated cuttings was $29 \pm 3,32 \pm$ 1 , and $26 \pm 2 \mathrm{C}$, respectively, and mean RH was $50 \% \pm 3 \%, 68 \% \pm 3 \%$, and $54 \%$ $+5 \%$, respectively (Serex model 229030 humidity reader; Bacharach, Pittsburgh). Air around misted cuttings averaged $1 \mathrm{C}$ lower and $\mathrm{RH}$ between mist episodes averaged 3\% higher than air around cuttings on the subirrigation bench at $1400 \mathrm{HR}$.

Rooting progress was monitored by sensing resistance when pulling gently on the stems. Trays were removed from flats after $90 \%$ of subirrigated 'Franksred' red maple, 'Charm' chrysanthemum, and coleus rooted and $90 \%$ of subirrigated Japanese tree lilac formed callus. Thereafter, trays were irrigated to container capacity from the" top twice a week with the fertilizer solution until harvest. Coleus and 'Charm' chrysanthemum were removed from flats after 9 days and stayed on the bench in the trays 5 more days before harvest. 'Franksred' red maple were removed from flats 2 weeks after sticking and stayed on the bench for another 2 weeks. Japanese tree lilac cuttings were removed from flats after 6 weeks and stayed on the bench for another 4 weeks. Misted cuttings were moved to the subirrigation bench as they met the root and callus criteria used for subirrigated cuttings. Coleus and 'Charm' chrysanthemum were moved from the mist bench to the bench with subirrigated cuttings 9 days after insertion and remained there 5 days. 'Franksred' red maple and Japanese tree lilac remained on the mist bench throughout the rooting period. Misted cuttings placed on the subirrigation bench were irrigated to container capacity from the top twice weekly with the fertilizer solution.

Jiffy trays containing 10 samples were considered experimental units. At each harvest, percentage rooting was determined, and roots were collected and dried at $67 \mathrm{C}$ for $48 \mathrm{~h}$. Mean root dry mass of rooted cuttings over time was determined for all species. Analysis of variance (ANOVA) was done by using SAS (SAS Institute, Cary, N.C. ). Mean separation was performed by using Fisher's LSD at $P=$ 0.05. "Data expressed as percentages were transformed to the arcsine of the square root before means were separated.

Fertilization during subirrigation of 'Franksred' red maple. Subirrigation units held one cutting each and consisted of two containers. Plastic pots (volume $=242 \mathrm{~cm}^{3}$, bottom diameter $=53 \mathrm{~mm}$, height $=70$ $\mathrm{mm}$, top diameter $=63 \mathrm{~mm}$; Kord Products Ltd., Bramalea, Ontario, Canada) held coarse perlite and were suspended in polyethylene containers without drainage holes (volume $=473$ $\mathrm{cm}^{3}$, bottom diameter $=76 \mathrm{~mm}$, height $=100 \mathrm{~mm}$, top diameter $=90 \mathrm{~mm}$; Fisher Scientific, Pittsburgh). Cuttings of 'Franksred' red maple were prepared and inserted in the perlite as during the previous experiment.

Subirrigation solutions of Peters Excel all-purpose fertilizer 21N-2.2P$16.6 \mathrm{~K}$ in tap water at $0,3.6$, and 7.2 $\mathrm{mol} \mathrm{N} / \mathrm{m}^{3}$ were maintained $1 \mathrm{~cm}$ above the bottom of the inner pot by applications to the perlite surface every 2 days. Thirty replicates per treatment were initiated in a completely random design on 17 July 1993. The experiment was repeated beginning 17 Aug. 1994, with 15 replicates per treatment. Pots were arranged on a glasshouse bench
$1.2 \mathrm{~m}$ under shadecloth. During the first replication, mean \pm SD PPF, air temperature, and $\mathrm{RH}$ at $1400 \mathrm{HR}$ were $190 \pm 26 \mu \mathrm{mol} \cdot \mathrm{m}^{-2} \cdot \mathrm{s}^{-1}, 30 \pm 2 \mathrm{C}$, and $68 \% \pm 3 \%$, respectively. For the second replication, means \pm SD were $167 \pm 15$ $\mu \mathrm{mol} \cdot \mathrm{m}^{-2} \cdot \mathrm{s}^{-1}, 25 \pm 1 \mathrm{C}$, and $56 \% \pm 4 \%$, respectively.

Percentage rooting was determined after 2 weeks by sensing resistance when pulling gently on the stems. Cuttings were removed from the perlite after 4 weeks. Roots were counted and weighed after drying at $67 \mathrm{C}$ for 48 h. Chlorophyll content of $10-\mathrm{mm}-$ diameter disks of interveinal tissue was determined (Moran, 1982; Moran and Porath, 1980). Disks were from the original two leaves of each cutting; mass per disk was 50 to $60 \mathrm{mg}$. ANOVA was used for all dependent variables by using SAS, and means were separated as described for the first experiment.

\section{Results}

Comparison of subirrigation and mist. All cuttings of the two herbaceous taxa rooted in 9 days regardless of method and sticking date. Leaves of subirrigated 'Charm' chrysanthemum wilted during afternoons and regained turgidity in the evenings before cuttings rooted. Leaves were turgid continuously after roots formed. Leaves of subirrigated coleus were turgid throughout treatment. There was no leaf desiccation or abscission for subirrigated cuttings of either herbaceous taxon. Misted cuttings of both taxa remained turgid throughout treatment. For coleus, the mean root dry mass per cutting was $32 \mathrm{mg}$, and there was no difference between misted and subirrigated cuttings. Mean root dry mass per cutting of 'Charm' chrysanthemum was 42 and $31 \mathrm{mg}$ for misted and subirrigated cuttings, respectively (LSD $=8 \mathrm{mg})$. No visual differences between cuttings in the two treatments were apparent at harvest for either herbaceous taxon.

Leaves of subirrigated 'Franksred' red maple remained turgid and green throughout treatment. Under mist, leaves of cuttings were green during the first 2 weeks, but then turned yellow and red. Some misted leaves abscised at harvest. After 2 weeks, 5\% and $93 \%$ of misted and subirrigated cuttings had rooted, respectively (Table 1). At week $4,21 \%$ and $95 \%$ of misted and subirrigated cuttings had rooted, respectively (Table 1 ). Root dry mass 
of subirrigated cuttings was higher than that of misted cuttings (Table 1). There were no new shoots on misted cuttings at harvest, but $33 \%$ of subirrigated cuttings had developed shoots.

Leaf necrosis of Japanese tree lilac was observed under mist after 2 weeks. All leaves of misted cuttings had abscised after 8 weeks. Leaves appeared healthy during the first 3 weeks on subirrigated cuttings; sporadic leaf abscission occurred thereafter. Callus diameter, percentage of cuttings with living leaves, and rooting percentage were higher for subirrigated than misted cuttings, but method did not affect the percentage of cuttings with living callus (Table 2). Root dry mass of subirrigated cuttings in the first through fourth replication of the experiment was $88,100,8$, and $12 \mathrm{mg}$, respectively, whereas root dry mass of misted cuttings was $0 \mathrm{mg}$ for all replications. ANOVA showed a probability of a greater F statistic of 0.077 for the effect of rooting method on mean root dry mass. Some cuttings in both treatments rotted after they formed callus within the first 6 weeks of treatment. Rooting percentage correlated with the percentage of cuttings with living leaves (Pearson's correlation coefficient $=0.91, P=0.0015)$.

Fertization during subirrigation of Franksred' red maple. Leaves of unfertilized cuttings were chlorotic after 2 weeks, but leaves of fertilized cuttings remained green. Greater than $90 \%$ of fertilized cuttings rooted within 2 weeks, whereas $8 \%$ and $65 \%$ of unfertilized cuttings rooted after 2 and 4 weeks, respectively (Table 3). Mean root mass was highest for

Table 1. Rooting percentages after 2 and 4 weeks, root dry ream, and shoot initiation of singlenode cuttings of 'Franksred' red maple provided intermittent mist or subirrigation for 4 weeks. Each value is the mean of four replications over time. Within columns, means followed by the same letter are not significantly different according to the least significant difference (LSD) test at $P=0.05 . L S D$ tesing on data expressed as percentages were determined after values were transformed to the arcsine of the square root.

\begin{tabular}{lcccr}
\hline Treatment & $\begin{array}{c}\text { Rooting at } \\
\text { week 2 (\%) }\end{array}$ & $\begin{array}{c}\text { Rooting at } \\
\text { week 4 (\%) }\end{array}$ & $\begin{array}{c}\text { Root dry } \\
\text { mass (m) }\end{array}$ & $\begin{array}{c}\text { Shoot } \\
\text { development (\%) }\end{array}$ \\
\hline $\begin{array}{l}\text { Mist } \\
\text { Subirrigation }\end{array}$ & $5 \mathrm{~b}$ & $33 \mathrm{~b}$ & $38 \mathrm{~b}$ & $\mathbf{0} \mathrm{b}$ \\
\hline
\end{tabular}

Table 2. Percentage of cuttings with living callus, callus diameter, percentage of cuttings with living leaves, and rooting percentage of Japanese tree lilac after 10 weeks in mist or in subirrigation. Callus was considered living if it was white rather than brown. Leaves were considered living if any portion of the leaf blade was green. Each value is the mean of four replicates. Within columns, means followed by the same letter are not significantly different according to the least significant difference (LSD) test at $P=0.05$. LSD tests on data expressed as percentages were determined after values were transformed to the arcsine of the square root.

\begin{tabular}{|c|c|c|c|c|}
\hline Treatment & $\begin{array}{l}\text { Cuttings } \\
\text { with living } \\
\text { callus (\%) }\end{array}$ & $\begin{array}{l}\text { Callus } \\
\text { diam } \\
(\mathrm{mm})\end{array}$ & $\begin{array}{l}\text { Cuttings } \\
\text { with living } \\
\text { leaves }(\%)\end{array}$ & $\begin{array}{c}\text { Rooting } \\
(\%)\end{array}$ \\
\hline Mist & $45 a$ & $63 \mathrm{~b}$ & $0 \mathrm{~b}$ & $0 \mathrm{~b}$ \\
\hline Subirrigation & $77 a$ & $124 \mathrm{a}$ & $28 \mathrm{a}$ & $21 \mathrm{a}$ \\
\hline
\end{tabular}

Table 3. Rooting percentages after 2 and 4 weeks, root dry mass, and number of roots on cuttings of 'Franksred' red maple subirrigated with solution containing three concentrations of $N$ fertilizer. Values are means from two replicate experiments in which 45 observations per treatment were made. Within columns, means followed by the same letter are not significantly different according to the least significant difference (LSD) test at $P=0.05$. LSD tests on data expressed as percentages were determined after values were transformed to the arcsine of the square root.

\begin{tabular}{lcccc}
\hline $\begin{array}{l}\text { Fertilizer } \\
\text { concn } \\
\left(\mathbf{m o l ~ N} / \mathbf{m}^{3}\right)\end{array}$ & $\begin{array}{c}\text { Rooting } \\
\text { at week } 2 \\
(\%)\end{array}$ & $\begin{array}{c}\text { Rooting } \\
\text { at week } \\
(\%)\end{array}$ & $\begin{array}{c}\text { Root dry } \\
\text { mass }(\mathbf{m g})\end{array}$ & $\begin{array}{c}\text { Roots } \\
(\text { no. })\end{array}$ \\
\hline 0 & $8 \mathrm{~b}$ & $65 \mathrm{a}$ & $45 \mathrm{c}$ & $23 \mathrm{~b}$ \\
3.6 & $93 \mathrm{a}$ & $93 \mathrm{a}$ & $163 \mathrm{~b}$ & $57 \mathrm{a}$ \\
7.2 & $95 \mathrm{a}$ & $95 \mathrm{a}$ & $206 \mathrm{a}$ & $62 \mathrm{a}$ \\
\hline
\end{tabular}

cuttings provided with $7.2 \mathrm{~mol} \mathrm{~N} / \mathrm{m}^{3}$ and lowest for unfertilized cuttings (Table 3). Root number was lowest for unfertilized cuttings and was similar for all cuttings treated with $\mathrm{N}$ (Table 3). After 4 weeks, $0 \%, 24 \%$, and $40 \%$ of cuttings treated with $0,3.6$, and 7.2 $\mathrm{mol} \mathrm{N} / \mathrm{m}^{3}$ had developed new shoots, respectively. Chlorophyll content of leaves was $1.8,3.2$, and $3.4 \mathrm{mg} \cdot \mathrm{g}^{-1}$ fresh mass for cuttings provided with $0,3.6$, and $7.2 \mathrm{~mol} \mathrm{~N} / \mathrm{m}^{3}$, respectively $(\mathrm{LSD}=0.2)$.

\section{Discussion}

Subirrigation can be a viable alternative to applying mist when propagating plants from stem cuttings. All subirrigated cuttings of 'Charm' chrysanthemum and coleus rooted, and dry mass of roots on subirrigated and misted cuttings was similar. Stresses associated with the periodic wilting of leaves of unrooted cuttings of 'Charm' chrysanthemum in subirrigation trays may account for the relatively low root dry mass of these cuttings. Yet foliar stress was not sufficient to damage leaves permanently or to reduce the percentage of cuttings that rooted, and we noted no visual differences in extent or apparent fictional quality of the roots that formed in the two treatments. Future research should determine how higher PPF and various temperature and $\mathrm{RH}$ regimes affect the success of using subirrigation.

Subirrigation was superior to mist for rooting stem cuttings of 'Franksred' red maple (Table 1), particularly when fertilizer was used (Table 3). Rooting of single-node cuttings of this taxon under mist typically requires four to six weeks, and rooting percentages have ranged from $26 \%$ to $96 \%$ (Smalley and Dirr, 1987; Still and Lane, 1982; Wilkins et al., 1995). In addition to the relatively slow rate of rooting under mist, chlorosis and desiccation of leaves after removal from mist may retard growth of propagules after rooting (Wilkins et al., 1995). Chlorosis of misted cuttings might indicate foliar nutrient deficiencies from leaching or an increase in cutting mass during rooting (Feldman et al., 1984; Good and Tukey, 1966). Methods we used for misting are consistent with recommendations (Dirr and Heuser, 1987), but it is possible that modifying the mist regime, applying fertilizer, or altering the greenhouse environment would have improved rooting with 
mist. However, achieving better rooting under mist would not alter the conclusion that subirrigation can replace mist and result in high percentages of well-rooted cuttings of this taxon.

Japanese tree lilac did not root satisfactorily with either method, but callus and root development were better with subirrigation than with mist (Table 2). Leiss (1981) reported 87\% rooting for this species when 20- to 25 -cm-long cuttings with multiple nodes were used. It is possible that the rooting potential of our cuttings was low because of the stem length $(5 \mathrm{~cm})$ and the presence of only one node. The correlation of rooting and leaf retention indicates that photosynthesis of Japanese tree lilac must be sustained during propagation. Additional studies with larger stem cuttings with more leaves should be done before drawing conclusions concerning the effectiveness of subirrigation with this species.

\section{Literature Cited}

Blazicb, F.A. 1988. Mineral nutrition and adventitious rooting, p. 61-69. In: T.D. Davis, B.E. Haissig, and N. Sankhla (eds.). Adventitious root formation in cuttings. Dioscorides Press, Portland, Ore.

Booze-Daniels, J.N., R.D. Wright, and R.E. Lyons. 1984. Effect of timed fertilizer application on Ilex crenata 'Helleri' cuttings during propagation. J. Environ. Hort. 2:43-45.

Dirr, M.A. and C.W. Heuser, Jr. 1987. The reference manual of woody plant propagation: From seed to tissue culture. Varsity, Athens, Ga.

Feldman, W. R., D.A. Palzkill and L. Hogan. 1987. Mineral nutrition of jojoba cuttings during mist propagation: Effect on rooting and growth. App. Agr. Res. 2:345-349.

Feldman, W. R., D. A. Palzkill, and L. Hogan. 1984. Leaf element concentrations of jojoba cuttings during vegetative propagation as related to nutrition and growth. Comm. Soil Sci. Plant Anal. 15:353-373.
Good, G.L. and H.B. Tukey,Jr. 1966. Leaching of metabolizes from cuttings propagated under intermittent mist. Proc. Amer. Soc. Hort. Sci. 89:727-733.

Hartmann, H.T., D.E. Kester, and F.T. Davies, Jr. 1990. Plant propagation: Principles and practices. 5th ed. Prentice Hall, Englewood Cliffs, N.J.

James, B.L. 1980. Propagation without mist. Proc. Intl. Plant Prop. Soc. 30:373-475.

Leiss, J. 1981. Propagation of Syringa reticulate and its forms. Proc. Intl. Plant Prop. Soc. 31:515-518.

Moran, R. 1982. Formulae for determination of chlorophyllous pigments extracted with $N, N$-dimethylformamide. Plant Physiol. 69:1376-1381.

Moran, R. and D. Porath. 1980. Chlorophyll determination in intact tissues using $N, N$-dimethylformamide. Plant Physiol. 65:478-479.

Morton, W.M. and J.W. Boodley. 1969. The effect of mist-fertilizer propagation on the growth and nutrient content of Euphobia pulcherrima and Chrysanthemum morifo lium. J. Amer. Soc. Hort. Sci. 94:549559.

Smalley, D.J. and M.A. Dirr. 1987. Effect of cutting size on rooting and subsequent growth of Acer rubrum 'Red Sunset' cuttings. J. Environ. Hort. 5:122-124.

Snyder, W.E. 1965. A history of mist propagation. Proc. Intl. Plant Proc. Soc. 15:6367.

Still, S.M. and B.H. Lane. 1982. Effects of fertilizer in the propagation medium and extended photoperiod on rooting of Acer rubrum 'Red Sunset'. Ohio Agr. Res. Dev. Ctr. 268:9-12.

Wilkins, L.C., W.R. Graves, and A.M. Townsend. 1995. Development of plants from single-node cuttings differs among cultivars of red maple. HortScience 30:360362.

Wott, J.A. and H.B. Tukey, Jr. 1967. Influence of nutrients mist on the propagation of cuttings. Proc. Amer. Soc. Hort. Sci. 90:455-461.

Zhang, H. and W.R. Graves. 1994. Subirrigation permits rooting of softwood cuttings of red maple without mist or fog. HortScience 29:570. (Abstr.) 